\title{
New state record of Lopesia grandis Maia, 2001 (Insecta, Diptera, Cecidomyiidae)
}

\author{
Valéria Cid Maia \\ Museu Nacional, Departamento de Entomologia, 20.940-040 Rio de Janeiro, RJ, Brazil \\ E-mail: maiavcid@acd.ufrj.br
}

\begin{abstract}
Lopesia grandis (Insecta, Diptera, Cecidomyiidae) is recorded for the first time in the state of Bahia. This species induces leaf galls on Dalbergia ecastophyllum (L.) Taub. (Fabaceae). The previous records included only the states of Rio de Janeiro and São Paulo, so the geographic distribution of this galling species is extended to the Northeast region of Brazil.
\end{abstract}

Key words: gall midge, geographic distribution, Fabaceae

Lopesia Rübsaamen, 1908 (Diptera, Cecidomyiidae) is known from 23 galling species. The genus is mainly Neotropical, but includes one Nearctic, three Afrotropical, and one Australasian species (Gagné and Jaschhof 2014). In Brazil, Lopesia is represented by 18 described species, but there are records of five undetermined species, which are probably new (Maia and Ascendino 2011).

The genus has indistinct limits that comprises species with three or four-segmented palpi; male antennae with binodal or gynecoid flagellomeres, and three separate circumfila or interconnected circumfila (as in female); $\mathrm{R}_{5}$ joining $C$ beyond the wing apex; Rs closer to the end of $\mathrm{R} 1$ than to the arculus; tarsal claws bowed near the basal third, generally toothed (simple only in L. licaniae Gagné, 1996); ovipositor short, barely protrusible and female cerci separate (Maia et al. 2010).

The species of this genus are easily recognizable based on morphological characters. Males, females, as well as larvae and pupae are important for identification. Rodrigues and Maia (2010) published an illustrated key to segregate the known species of Lopesia based on all described stages of the life cycle. Furthermore, the gall morphology is very useful to species identification, as it is unique to each galling species.

Lopesia grandis Maia, 2001 (Diptera, Cecidomyiidae) is a gall midge that induces leaf galls on Dalbergia ecastophyllum (L.) Taub. (Fabaceae), a plant commonly known as "rabo-de-bugio" or "marmelo-do-mangue". It differs from other known Lopesia species in having the following combination of characters: 4-toothed spatula (larva), upper frontal spine (pupa), circumfila loops very short (male), 4-segmented palpi, and tarsal claw toothed (adult) (Maia 2001).

Dalbergia ecastophyllum occurs throughout the tropics of the Old and New Worlds. In the Neotropical region, it has been recorded from Florida (USA) to the Southern Brazil, reaching the state of Santa Catarina (Maia 2001). It is a scandent or semi-prostrate species, well adapted to high salinity, and with floating fruits, being easily found in estuaries, dunes, and mangroves, where helps to fix sand (Carvalho 1997).

This plant produces the red propolis, known by its high concentration of isoflavonoids and high antimicrobial, antioxidant and antifungal activities, being used in combating uterine inflammation, anemia, and menopausal symptoms, such as hot flashes, mood swings, osteoporosis, and ovarian cancer (Keller 2011). Therefore, it is an economically important plant.

Lopesia grandis Maia, 2001 was described based on specimens from the municipality of Maricá (state of Rio de Janeiro). Later, this gall midge was recorded in other restinga areas of the same state: Ilha Grande (municipality of Angra dos Reis), Carapebus, Jurubatiba, Camboinhas (municipality of Niterói), and Parque Ecológico Chico Mendes (municipality of Rio de Janeiro), as well as in the state of São Paulo (municipality of Bertioga) (Oliveira and Maia 2005; Maia 2001; Monteiro et al. 2004; Maia and Barros 2009; Maia et al. 2008, respectively). In this paper, the geographic distribution of Lopesia grandis is widened.

The coastal vegetation of Porto Seguro (state of Bahia, Northeast region, Brazil) was surveyed along 12 $\mathrm{km}$, from Mucugê Beach in Arraial da Ajuda ( $16^{\circ} 28^{\prime} 26^{\prime \prime} \mathrm{S}$, $\left.039^{\circ} 08^{\prime} 56^{\prime \prime} \mathrm{W}\right)$ to Coqueiros Beach in Trancoso $\left(16^{\circ} 32^{\prime} 27\right.$ $\mathrm{S}$, $039^{\circ} 06^{\prime} 28^{\prime \prime} \mathrm{W}$ ) (Figure 1), in September 2013, for 8 hours by two people.

Individuals of Dalbergia ecastohyllum were investigated 


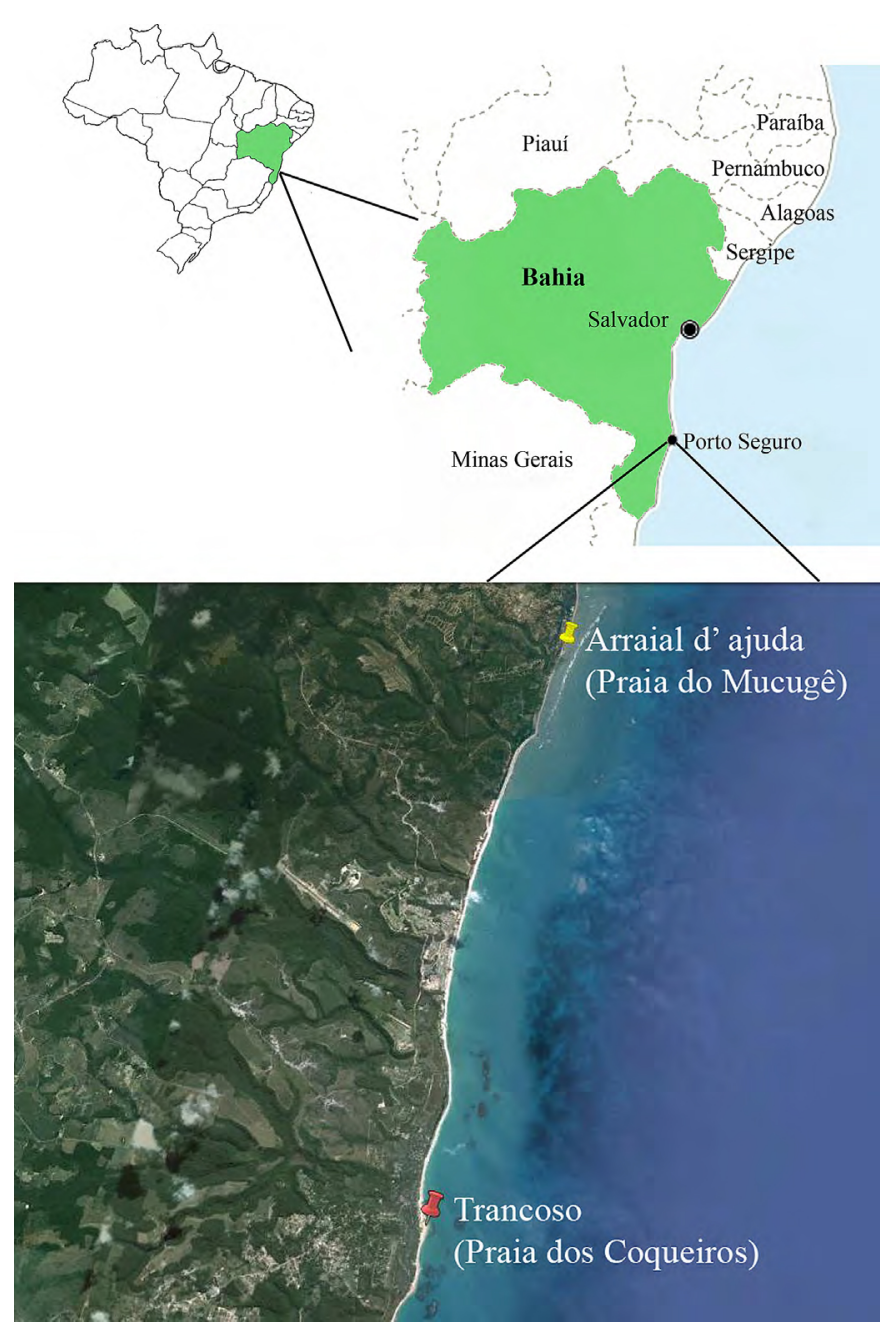

Figure 1. Investigated area in Porto Seguro (Bahia, Brazil): from Praia do Mucugê (Arraial d'Ajuda) to Praia dos Coqueiros (Trancoso). From Google Maps 2014.

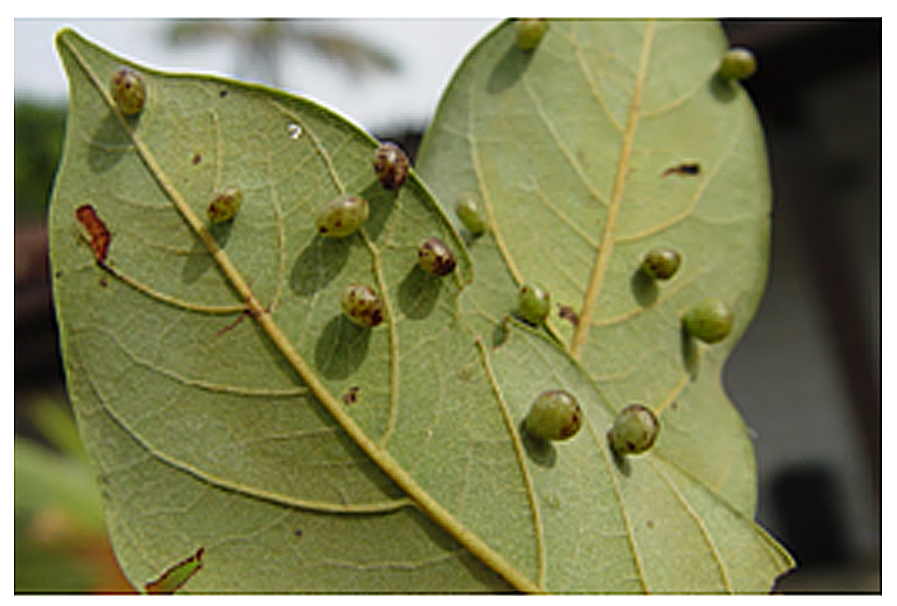

Figure 2. Galls of Lopesia grandis Maia, 2001 (Diptera, Cecidomyiidae) on leaves of Dalbergia ecastophyllum (L.) Taub. (Fabaceae).

for insect galls. The host plant was identified by the author. Galled leaves were photographed in field using a digital camera (Figure 2). Fifteen galls were removed from the host plant and transported in plastic bags: 10 were dissected in the laboratory, using a hand-held magnifier and five were dried and pressed. Seven galling larvae were
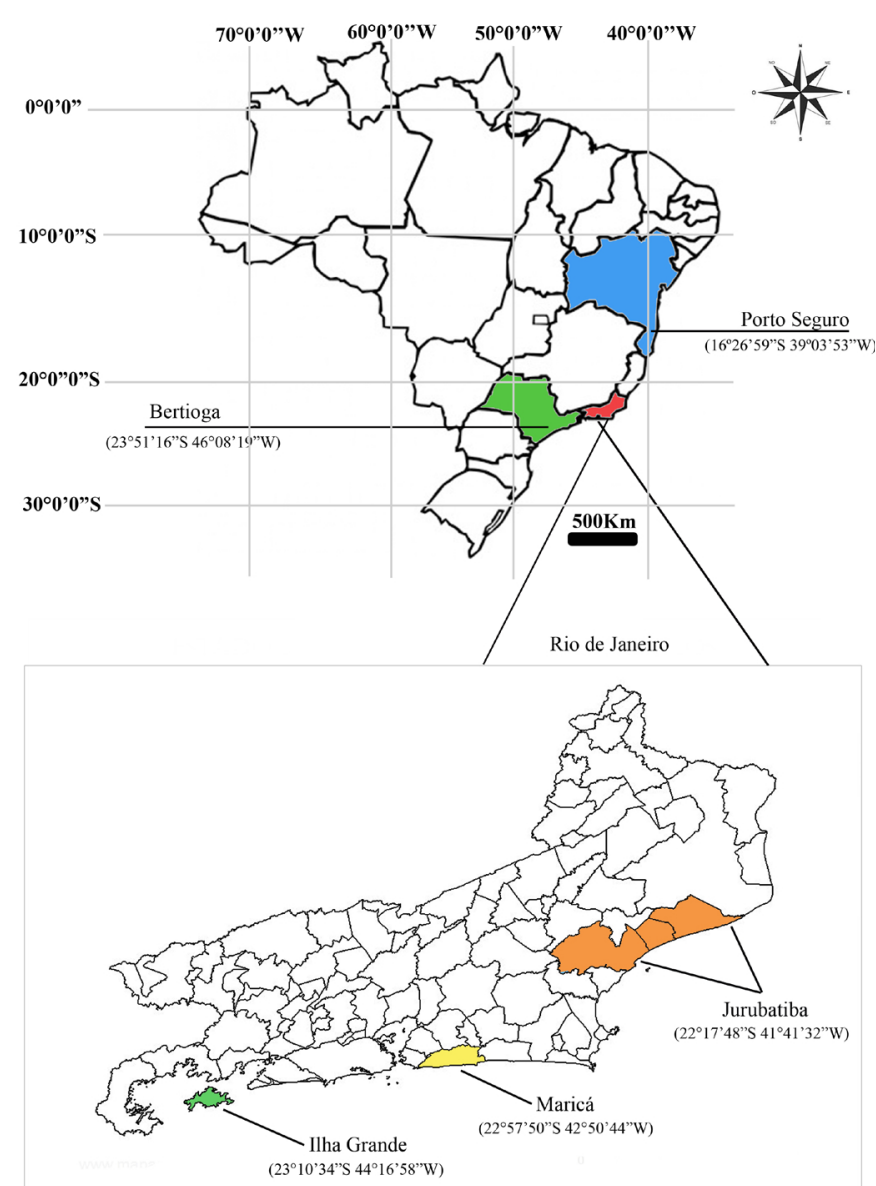

Figure 3. Maps of Brazilian states and of Rio de Janeiro, showing the geographic distribution of Lopesia grandis Maia, 2001 (Diptera, Cecidomyiidae).

removed from the dissected galls and mounted on microscope slide, following the methods of Gagné (1994); the three other galls were already empty. The mounted larvae and the dried galls were deposited in the collection of the Museu Nacional/Universidade Federal do Rio de Janeiro as voucher material. The gall midge species was identified based on both gall and larva morphology, according to the descriptions of Maia (2001).

Leaf galls were found on Dalbergia ecastophyllum (Fabaceae). The galling species was identified as Lopesia grandis (Diptera, Cecidomyiidae). This midge has been recorded in restinga areas of Rio de Janeiro and São Paulo states (Maia 2013), so its geographic distribution was restricted to the Southeast region of Brazil. The new occurrence in Porto Seguro (Bahia) expands its area of distribution to the Northeast region of our country (Figure 3). All recorded localities are inserted in the Atlantic Forest (including the new one), suggesting that Lopesia grandis is restricted to this biome. Nevertheless, the host plant occurs also in the Amazonian Forest. As the host plant species is wide-spread in the tropics, Lopesia grandis can also have a wider distribution. It is necessary to survey the whole area of distribution of Dalbergia ecastophyllum to define the pattern of distribution of this galler. 


\section{ACKNOWLEDGEMENTS}

I am grateful to Dr. Bernardo Mascarenhas (Museu Nacional/Universidade Federal do Rio de Janeiro) for field assistance and to $\mathrm{CNPq}$ for financial support (Proc. 306278/2013-8).

\section{LITERATURE CITED}

Carneiro, M.A.A., C.S.A. Branco, C.E.D. Braga, E.D. Almada, M.B.Costa, V.C. Maia and G.W. Fernandes. 2009. Are gall midge species (Diptera, Cecidomyiidae) host-plant specialists? Revista Brasileira de Entomologia 53(3): 365-378.

Carvalho, A.M.A. 1997. Synopsis of the genus Dalbergia (Fabaceae: Dalbergiae) in Brazil. Brittonia 49(1): 87-109.

Gagné, R.J. 1994. The gall midges of the Neotropical Region. Ithaca, Comell University Press. 352 pp.

Gagné, R.J and M. Jaschhof. 2014. A catalog of the Cecidomyiidae (Diptera) of the world. 3rd edition. Digital version 2.

Keller, F. 2011. The unique antioxidant, cytotoxic, and isoflavonoid factors of Brazilian red propolis from Dalbergia ecastophyllum (L.) Taubert (Leguminosae). Journal of the American Apitherapy Society 18(1): 1-6.

Maia, V.C. 2001. The gall midges (Diptera, Cecidomyiidae) from three restingas of Rio de Janeiro State, Brazil. Revista Brasileira de Zoologia 18(2): 583-629. doi: 10.1590/So101-81752001000200028

Maia, V.C. 2013. Galhas de insetos em restingas da região sudeste do Brasil com novos registros. Biota Neotropica 13(1): 183-209. doi: 10.1590/S1676-06032013000100021

Maia, V.C. and S. Ascendino. 2011. Representatividade do gênero Lopesia Rübsaamen (Diptera, Cecidomyiidae) no Brasil. Papéis
Avulsos de Zoologia 51(23): 359-365. doi: 10.159o/Soo3110492011002300001

Maia, V.C. and G.P.S. Barros. 2009. Espécies de Cecidomyiidae (Diptera) registradas no Estado do Rio de Janeiro, Brasil. Arquivos do Museu Nacional 67(3-4): 211-220.

Maia, V.C, G.W. Fernandes, H. Magalhães and J. C. Santos. 2010. Two new species of Lopesia Rübsaamen (Diptera, Cecidomyiidae) associated with Mimosa hostilis (Mimosaceae) in Brazil. Revista Brasileira de Entomologia 54(4): 578-583. doi: 10.1590/Soo8556262010000400007

Maia, V.C., M.A.G. Magenta and S.E. Martins. 2008. Ocorrência e caracterização degalhas deinsetos emáreas derestinga de Bertioga (São Paulo, Brasil). Biota Neotropica 8(1): 167-197. http://www. biotaneotropica.org.br/v8n1/pt/fullpaper?bno2408012008+pt

Monteiro, R.F., R.A.M. Oda, K.L. Narahara and P.A.L. Constantino. 2004. Galhas: Diversidade, Especificidade e Distribuição; pp. 127-141, in: C.F.D. Rocha, F.A. Esteves and F.R. Scarano (orgs.). Pesquisa de Longa Duração na Restinga de Jurubatiba: Ecologia, História Natural e Conservação. São Carlos: RiMa Editora.

Oliveira, J.C. and Maia, V.C. 2005. Ocorrência e caracterização de galhas de insetos na restinga de Grumari (Rio de Janeiro, RJ, Brasil). Arquivos do Museu Nacional 63(4): 669-675.

Rodrigues, A. R. R. and V.C. Maia. 2010. Duas novas espécies de Lopesia Rübsaamen (Diptera, Cecidomyiidae) do Brasil, com chave para as espécies. Biota Neotropica 10(1): 85-99. doi: 10.1590/S1676-06032010000100008

Received: November 2013

Accepted: March 2015

Editorial responsibility: Jonas da Silva Döge 